Jurnal Psikologi Teori dan Terapan

2016, Vol. 6, No. 2, 71-77, ISSN: 2087-1708

\title{
Motivasi Berprestasi dengan Stres Kerja Pada Guru Taman Kanak-Kanak
}

\author{
Maulinda Nur Nafiah dan Hermien Laksmiwati \\ Program Studi Psikologi Universitas Negeri Surabaya
}

\begin{abstract}
The purpose of this study was to determine the correlation between achievement motivation and working stress on kindergarten teachers in Sooko Subdistrict, Mojokerto Regency, East Java. The subjects were 53 kindergarten teachers who are the members of Ikatan Guru Taman Kanak-kanak Indonesia (IGTKI). Data collected using achievement motivation and working stress scales and analyzed using product moment correlation. The result shows that the coefficient correlation is $-0,672$ in the level of significant of 0,000 $(p \leq 0,05)$. It means that there is significant negative correlation between achievement motivation and working stress. The result indicates that the higher achievement motivation correlates with the lower working stress. The achievement motivation gives $67,2 \%$ contribution in affecting working stress, while the rest $32,8 \%$ were contributed by other factors.
\end{abstract}

Keywords: Achievement motivation, working stress, kindergarten teachers

\begin{abstract}
Abstrak: Penelitian ini bertujuan untuk mengetahui hubungan antara motivasi berprestasi dengan stres kerja pada guru Taman Kanak-Kanak di Kecamatan Sooko. Subjek penelitian ini adalah 53 guru Taman Kanak-Kanak anggota Ikatan Guru Taman Kanak-kanak Indonesia (IGTKI). Penelitian ini menggunakan instrumen skala motivasi berprestasi dan skala stres kerja yang dianalisis menggunakan korelasi product moment. Hasil analisis menunjukkan koefisien korelasi sebesar $-0,672$ pada level signifikansi $0,000 \quad(p \leq 0,05)$. Hasil ini menunjukkan adanya korelasi negatif yang signifikan antara motivasi berprestasi dan stres kerja. Semakin tinggi motivasi berprestasi, maka akan semakin rendah stres kerja. Motivasi berprestasi memberikan kontribusi sebesar $67,2 \%$ pada stres kerja, dimana 32,8\% dikontribusikan oleh variabel lain yang tidak diteliti dalam penelitian ini.
\end{abstract}

Kata kunci: Motivasi berprestasi, stres kerja, guru taman kanak-kanak.

Pendidikan menurut Undang-undang nomor 20 tahun 2003 merupakan suatu usaha sadar dan terencana untuk mewujudkan suasana belajar dan proses pembelajaran. Tujuan pendidikan tidak lain agar peserta didik secara aktif mengembangkan potensi diri untuk memiliki kekuatan spiritual keagamaan, pengen- dalian diri, kepribadian, kecerdasan, akhlak mulia, serta keterampilan yang diperlukannya, masyarakat, bangsa, dan negara. Pendidikan formal di Indonesia dimulai dari jenjang pendidikan usia dini hingga pendidikan tinggi.

Menurut Herwanto (2004) salah satu pekerjaan yang memiliki peranan penting

Korespondensi tentang artikel ini dapat dialamatkan kepada Maulinda Nur Nafiah melalui email:maulinda.nafiah@gmail.com 
dalam mengembangkan kemampuan anak usia dini adalah guru Taman Kanak-kanak (TK). Guru TK wajib memiliki kualifikasi akademik dan kompetensi guru. Menurut Permendiknas No. 58 tahun 2009, kualifikasi secara akademik dibuktikan dengan kepemilikan ijazah, sedangkan kompetensi yang wajib dimiliki ada empat, yaitu kompetensi kepribadian, kompetensi profesional, kompetensi pedagogik, dan kompetensi sosial.

Menurut Wardana (2013) guru TK diharuskan meningkatkan kinerja dan kompetensi yang dimiliki untuk meningkatkan mutu pendidikan. Guru TK diharapkan dapat bekerja lebih efisien dengan memanfaatkan kemajuan teknologi dan membuat inovasi dalam dunia pendidikan. Mardjuki (dalam Wardana, 2013) berpendapat bahwa kinerja guru harus selalu ditingkatkan, mengingat tantangan dunia pendidikan untuk menghasilkan kualitas sumber daya manusia yang mampu bersaing di era global yang semakin ketat, hal ini bisa dilihat dari keikutsertaan guru-guru TK di Kecamatan Sooko dalam berbagai kegiatan. Tujuannya tidak lain untuk meningkatkan kompetensi yang dimiliki.

Kesibukan guru-guru TK mulai semakin terasa sejak adanya Penilaian Kompetensi Guru (PKG) yang dilakukan secara menyeluruh. Tujuan diadakannya PKG ini adalah untuk menilai kinerja guru secara menyeluruh selama tenggang waktu satu tahun. Penilaian dilakukan oleh kepala sekolah, teman seprofesi, surveyor dari Unit Pelaksana Teknis Dinas Pendidikan, dan dari ujian yang dilaksanakan secara online. Data ini diungkap dari wawancara kepada kepala sekolah TK di Kecamatan Sooko yang dilakukan selama Bulan Maret 2015.

Menurut Rosyidah, Kepala Sekolah TK Ihyaul Ulum, sejak adanya PKG yang dilakukan secara menyeluruh, guru-guru di TK Ihyaul Ulum saat ini mulai disibukkan dengan kegiatan-kegiatan untuk meningkatkan kompetensi diri. Hasil rata-rata
PKG tahun 2014, guru-guru di TK Ihyaul Ulum mendapatkan nilai 44 dari skala 1-56. Nilai tersebut berarti guru-guru perlu meningkatkan kemampuannya dengan mengikuti pelatihan, seminar, lomba, maupun penelitian. Berbagai kegiatan ini rupanya berakibat pada meningkatnya absensi kehadiran di sekolah. Guru-guru sering mengeluh penurunan kesehatan karena pada hari sebelumnya ada kegiatan pelatihan atau sedang mengerjakan penelitian. Guru tersebut akhirnya tidak dapat hadir di sekolah karena sakit. Beban kerja guru yang hadir semakin meningkat, ketika intensitas ketidakhadiran guru lain meningkat. Guru yang hadir diharuskan meng-handle kelas yang kosong, akibatnya guru kurang dapat mengontrol emosi di kelas yang pada akhirnya membuat pembelajaran berjalan kurang maksimal.

Wawancara selanjutnya dilakukan kepada Kepala TK Kuncup Melati yang menyatakan bahwa guru-guru menjadi sering mengeluhkan pembelajaran di kelas. Banyaknya pekerjaan yang menumpuk dan perlu diselesaikan akibat sering menunda pekerjaan, menyebabkan guru kurang memperhatikan pekerjaan di sekolah, meskipun pekerjaan tersebut tergolong pekerjaan kecil, misalnya merekap nilai harian siswa yang seharusnya dilakukan setiap hari. Guru juga sering tidak menyediakan Alat Permainan Edukatif (APE) yang seharusnya disediakan untuk pembelajaran, akibatnya murid menerima materi yang tidak sesuai dengan Rencana Kegiatan Harian (RKH).

Kepala TK Al-Ihsan juga menuturkan bahwa banyaknya pekerjaan yang diampu oleh guru TK menyebabkan guru sering mengalami sakit kepala. Sakit kepala dikeluhkan saat guru mengajar di kelas. Wawancara selanjutnya dilakukan pada guru Al-Ihsan untuk mengklarifikasi mengapa guru tersebut mengalami sakit kepala. Guru tersebut menuturkan bahwa sakit kepala bukan hanya terjadi pada saat di kelas. Sakit kepala terjadi berkelanjutan karena banyak memikirkan pekerjaan yang 
belum terselesaikan. Pekerjaan yang dimaksud bukan hanya pekerjaan pokok sebagai guru, namun juga tugas-tugas pemberkasan dari Dinas Pendidikan Kabupaten Mojokerto yang menuntut waktu singkat untuk dikerjakan, menjadikan pekerjaan semakin menumpuk dan membuatnya sulit berkonsentrasi.

Wawancara selanjutnya dilakukan pada kepala sekolah TK Insan Cita. Beliau menyatakan bahwa kurangnya guru yang mau bersaing untuk mengembangkan sekolah menyebabkan guru sering tidak bekerja maksimal. Guru yang sering terlambat, dan pulang lebih cepat mengakibatkan banyaknya pekerjaan sekolah yang dikerjakan di rumah, namun pada akhirnya pekerjaan itu tidak dikerjakan. Wawancara lebih lanjut, dilakukan pada guru TK Insan Cita, yang menyatakan banyaknya pekerjaan sekolah dan pekerjaan rumah membuat sakit kepala dan tekanan darah tinggi. Pekerjaan yang menumpuk menyebakan susah tidur dan tidur menjadi tidak teratur.

Berdasarkan hasil wawancara di atas, menunjukkan adanya fenomena stres kerja seperti yang disampaikan oleh Braham (dalam Rivai \& Mulyadi, 2009) dan adanya fenomena turunnya motivasi berprestasi McClelland (dalam Robbins \& Judge, 2008). Menurut Braham (dalam Rivai \& Mulyadi, 2009) stres kerja dapat dilihat melalui beberapa aspek, yaitu aspek fisik, emosional, intelektual, dan interpersonal. Aspek fisik terdiri atas terdiri atas tidur tidak teratur, sakit kepala, adanya gangguan pencernaan, kulit gatal-gatal, punggung terasa sakit, urat-urat pada bahu terasa tegang, keringat berlebih, tekanan darah tinggi, dan mudah lelah. Aspek emosional seperti mudah marah, mudah tersinggung, gelisah, sedih, dan gugup. Aspek intelektual meliputi kacaunya pikiran, mudah lupa, sulit berkonsentrasi, melamun berlebihan, dan hanya memikirkan pekerjaan. Aspek interpersonal meliputi tak acuh pada rekan kerja, kepercayaan pada orang lain menurun, mudah mengingkari janji pada orang lain, mencari kesalahan orang lain, dan mudah menyalahkan orang lain.

Fenomena stres kerja tersebut disertai adanya motivasi berprestasi guru yang menurun. Fenomena yang ada, berbanding terbalik dengan adanya aspek-aspek dasar individu dengan kebutuhan pencapaian yang tinggi yang disampaikan oleh McClelland (dalam Robbins \& Judge, 2008). Menurut McClelland (dalam Robbins \& Judge, 2008) aspek-aspek dasar individu dengan kebutuhan pencapaian yang tinggi, yaitu memiliki tanggung jawab pribadi, mempunyai keinginan untuk mendapat umpan balik yang jelas atas kinerjanya, dan memperhitungkan risiko mengambil keputusan atas pekerjaan. Ingarianti (2009) menambahkan bahwa ketika guru TK mengalami stres kerja, maka pekerjaan mengajar terlantar, sering mengeluh karena terganggu kesehatannya, dan cenderung marah-marah di kelas atau bahkan cenderung melampiaskan dengan kekerasan. Guru sebagai seorang panutan, maka seharusnya seorang guru harus mampu mengelola emosinya dengan baik.

Menurut Siagian (2007) stres yang berhubungan dengan lingkungan pekerjaan disebut sebagai stres kerja. Margiati (dalam Rivai \& Mulyadi, 2009) menyebutkan bahwa stres kerja yang berkepanjangan dapat merugikan individu maupun organisasi. Dampak-dampaknya meliputi individu bekerja melewati batas kemampuan, sering terlambat masuk kerja dan absen kerja, kesulitan membuat keputusan, dan lebih sering membuat kesalahan dalam bekerja. Dampak stres kerja yang lain meliputi lupa akan janji yang dibuat, kerisauan akan kesalahan yang dibuat, gangguan kesehatan, serta meningkatnya layanan program bantuan dan prosedur keluhan.

Menurut Braham (dalam Rivai \& Mulyadi, 2009) stres kerja merupakan suatu kondisi ketegangan yang mempengaruhi emosi, proses berpikir, dan kondisi seseorang, dimana seseorang terpaksa 
memberikan tenggapan melebihi kemampuan penyesuaian dirinya terhadap suatu tuntutan eksternal (lingkungan). Stres yang terlalu besar dapat mengancam kemampuan seseorang untuk menghadapi lingkungannya. Hasilnya dalam diri pekerja berkembang berbagai macam gejala stres yang dapat mengganggu pelaksanaan kerjanya.

Fenomena ini tidak hanya terjadi di Kecamatan Sooko saja, namun juga terjadi di Semarang. Lilik (2007) melakukan penelitian mengenai stres kerja guru yang terjadi di Semarang. Menurut Lilik (2007) guru memiliki tanggung jawab yang besar untuk memberikan pengajaran yang layak bagi perkembangan penerus bangsa. Berbagai tuntutan harus dipenuhi oleh seluruh guru. Hal tersebut menyebabkan terjadinya stres kerja pada guru.

Menurut Istijanto (2008) stres muncul saat seseorang tidak mampu memenuhi apa yang menjadi tuntutan tempatnya bekerja. Beberapa hal yang dapat memicu stres antara lain ketidakjelasan tanggung jawab pekerjaan, kekurangan waktu untuk menyelesaikan tugas, tidak adanya dukungan fasilitas untuk menyelesaikan pekerjaan, dan pekerjaan yang saling bertentangan. Menurut Mangkunegara (2010) salah satu penyebab tidak produktifnya pekerja yaitu karena pekerja tersebut mengalami stres kerja dan kurangnya motivasi untuk melakukan pekerjaan dengan lebih baik.

Greenberg \& Baron (dalam Yuwono dkk., 2005) menjelaskan bahwa motivasi adalah suatu proses yang membangkitkan, mengarahkan, dan memelihara perilaku manusia agar terarah pada tujuan. Manusia memiliki berbagai kebutuhan, ketika muncul suatu kebutuhan yang kuat di dalam diri seseorang, kebutuhan tersebut memotivasi dirinya untuk menunjukkan perilaku yang dapat mendatangkan kepuasannya. McClelland (dalam Robbins \& Judge, 2008) mengemukakan bahwa individu mempunyai cadangan energi potensial, bagaimana energi ini dilepaskan dan dikembangkan tergantung pada kekuatan atau dorongan motivasi individu dan situasi serta peluang yang tersedia. Salah satu bentuk motivasi yang disampaikan McClelland (dalam Robbins \& Judge, 2008) adalah motivasi berprestasi. Menurut McClelland (dalam Robbins \& Judge, 2008) motivasi berprestasi mendorong seseorang untuk mencapai keberhasilan dalam bersaing dengan suatu ukuran keunggulan (standard of excellence), baik berasal dari standar prestasinya sendiri (autonomous standards) di waktu lalu ataupun prestasi orang lain (social comparison standard). Penelitian lain tentang motivasi, datang dari Wardana (2013) tentang motivasi guru di Jember. Wardana (2013) menemukan bahwa guru-guru yang sudah disertifikasi memiliki kinerja yang belum memuaskan. Salah satu faktor yang mempengaruhi kinerja guru tersebut adalah motivasi berprestasi. Motivasi berprestasi secara signifikan berpengaruh pada kinerja guru di Jember.

Studi pendahuluan dilakukan kepada 23 kepala sekolah taman kanak-kanak di Kecamatan Sooko. Terdapat 23 sekolah taman kanak-kanak di Kecamatan Sooko dengan guru sejumlah 83 orang ditambah 23 kepala sekolah. Pemaparan yang disampaikan oleh beberapa kepala sekolah di Sooko tersebut menarik untuk diteliti, karena peneliti melihat begitu banyak masalah mengenai motivasi berprestasi dan stres kerja. Peneliti tertarik untuk meneliti mengenai hubungan antara motivasi berprestasi dan stres kerja dengan judul penelitian Hubungan Antara Motivasi Berprestasi dengan Stres Kerja pada Guru Taman Kanak-kanak di Kecamatan Sooko.

\section{Metode}

Penelitian ini menggunakan metode penelitian kuantitatif dengan rancangan penelitian korelasional untuk mengungkap hubungan motivasi berprestasi dengan stres kerja pada guru taman kanak-kanak di 
Kecamatan Sooko.

Populasi dalam penelitian ini adalah 83 guru taman kanak-kanak di Kecamatan Sooko. Teknik sampling dalam penelitian ini adalah sampel jenuh yaitu menggunakan seluruh populasi sebagai sampel penelitian. Sampel dibagi menjadi 30 orang untuk uji coba, dan sejumlah 53 orang sebagai subjek penelitian. Subjek uji coba diambil dengan membuat lotre yang diisi semua namanama subjek, sehingga semua mempunyai peluang yang sama untuk menjadi subjek uji coba, selanjutnya diambil 30 lotre yang menjadi subjek uji coba. Instrumen penelitian yang digunakan adalah skala motivasi berprestasi dan skala stres kerja dengan menggunakan model skala likert.

Penelitian ini menggunakan teknik analisis data product moment correlation karena penelitian ini bertujuan untuk mengetahui hubungan antara satu variabel bebas dengan satu varibel terikat. Variabel bebas dalam penelitian ini adalah motivasi berprestasi. Variabel terikat dalam penelitian ini adalah stres kerja. Analisis dilakukan dengan menggunakan bantuan program SPSS versi 17.00 for windows.

\section{Hasil dan Pembahasan}

Hasil analisis data menunjukkan nilai koefisien korelasi dari kedua variabel yang diteliti adalah sebesar $-0,672$ dan signifikasi atau probabilitasnya sebesar (p) $=0,000(\mathrm{p}<0,05)$. Hasil ini menunjukkan bahwa ada hubungan negatif yang signifikan antara motivasi berprestasi dengan stres kerja pada guru taman kanakkanak di Kecamatan Sooko. Semakin tinggi motivasi berprestasi, maka akan semakin rendah stres kerja. Hasil penelitian ini juga menunjukkan bahwa hubungan tidak searah antara motivasi berprestasi dengan stres kerja tersebut termasuk dalam korelasi tinggi.

Penelitian ini sesuai dengan beberapa penelitian sebelumnya melaporkan motivasi berprestasi memiliki hubungan yang tidak searah dengan stres kerja,
Penelitian Yulianti (2008) tentang pengaruh motivasi ber-prestasi terhadap stres kerja dan kinerja pada sejumlah manajer dan staf karyawan koperasi di Jawa Barat menemukan bahwa efek psikologis paling sederhana dari stres kerja adalah manurunnya motivasi dalam bekerja. Karena itu motivasi sangat dibutuhkan oleh pekerja sebagai dorongan untuk menciptakan gairah dan semangat dalam bekerja, sehingga dapat mengendalikan stres pada pekerja. Hidayat \& Prakosa (1997) mengkaji tentang hubungan motivasi berprestai dan stres kerja pada wartawan Republika. Hasil penelitian tersebut menunjukkan terdapat hubungan negatif antara motivasi berprestasi dengan stres kerja. Hasil ini didukung penelitian yang pernah dilakukan oleh Snead \& Harrel (1991) mengatakan bahwa individu yang memiliki motivasi berprestasi tinggi cenderung dapat mengurangi tingkat stres kerja.

Menurut McClelland (dalam Robbins \& Judge, 2008) motivasi berprestasi mendorong seseorang untuk mencapai keberhasilan dalam bersaing dengan suatu ukuran keunggulan (standard of excellence), baik berasal dari standar prestasinya sendiri (autonomous standards) diwaktu lalu ataupun prestasi orang lain (social comparison standard). McClelland (dalam Munandar, 2001) mengemukakan bahwa mereka dengan dorongan prestasi yang tinggi memiliki dorongan yang kuat untuk berhasil. Mereka berbeda dari orang lain dalam keinginan kuat mereka untuk melakukan pekerjaannya dengan lebih baik. Menurut McClelland (dalam Robbins \& Judge, 2008) aspek dasar individu dengan kebutuhan pencapaian yang tinggi yaitu memiliki tanggung jawab pribadi, adanya keinginan untuk mendapat umpan balik yang jelas atas kinerjanya, dan memperhitungkan risiko.

Menurut McClelland (dalam Robbins \& Judge, 2008) seseorang yang memiliki tanggung jawab pribadi yaitu seseorang 
yang mempunyai keinginan akan situasi yang memungkinkannya bertanggung jawab secara pribadi atas tindakan yang diambil dalam rangka mencapai tujuan atau menemukan pemecahan masalah. Individu akan berusaha menyelesikan pekerjaannya dengan baik agar semua pekerjaan selesai tepat waktu, tidak melempar tanggung jawab pada orang lain, dan puas dengan hasil pekerjaan. Individu dengan kebutuhan pencapaian yang tinggi menurut McClelland (dalam Robbins \& Judge, 2008) juga mempunyai keinginan untuk mendapat umpan balik yang jelas atas kinerjanya. Individu cenderung melihat imbalan hanya sebagai simbol keberhasilannya bukan sebagai pendorong tingkah-laku atau tujuan akhirnya. Individu lebih menyukai aktivitas yang memberikan umpan balik yang cepat dan tepat.

Beberapa faktor lain yang mempengaruhi motivasi berprestasi menurut McClelland (1987) di antaranya adalah konsep diri dan adanya pengakuan dan prestasi. Konsep diri merupakan bagaimana seseorang berpikir mengenai dirinya sendiri, apabila individu tersebut termotivasi untuk melakukan hal tersebut, sehingga ber-pengaruh pada tingkah lakunya. Dengan adanya pengakuan dan apresiasi atas prestasi, individu akan termotivasi untuk bekerja dengan baik karena ia merasa dipedulikan dan dihargai oleh orang lain. Faktor-faktor lain yang mempengaruhi stres kerja yang tidak diteliti dalam penelitian ini, antara lain faktor intrinsik dalam pekerjaan, peran dalam organisasi, pengembangan karir, hubungan dalam pekerjaan, serta struktur dan iklim organisasi (Munandar, 2001).

\section{Simpulan}

Berdasarkan hasil penelitian tentang hubungan antara motivasi berprestasi dengan stres kerja pada guru taman kanakkanak di Kecamatan Sooko, didapatkan hasil yang negatif dan signifikan. Hal ini berarti semakin tinggi tingkat motivasi berprestasi maka semakin rendah tingkat stres kerja yang dimiliki indiidu dan sebaliknya, semakin rendah tingkat motivasi berprestasi maka semakin tinggi tingkat stres individu tersebut jadi didapatkan simpulan bahwa terdapat hubungan antara motivasi berprestasi dengan stres kerja pada guru taman kanakkanak di Kecamatan Sooko.

Diharapkan bagi peneliti selanjutnya untuk dapat menggali mengenai stres kerja, faktor yang mempengaruhinya, dan mengkaji lebih cermat lagi mengenai faktor adanya stres kerja yang dialami oleh guru TK. Selain dari variabel yang telah dijelaskan oleh peneliti, masih ada faktor yang merupakan penentu stres kerja yang belum terungkap sepenuhnya. Variabelvariabel tersebut, pada penelitian selanjutnya, diharapkan untuk diteliti sehingga dapat diketahui faktor-faktor stres kerja pada guru TK pada khususnya, sehingga dapat menjadi acuan penyelesaian permasalahan yang terjadi.

\section{Daftar Pustaka}

Arikunto. S. (2009). Prosedur penelitian suatu pendekatan Praktik. (Edisi Keempat). Jakarta: Rineka Cipta.

Chaplin, J. P. (2006). Kamus Lengkap Psikologi. Terjemahan Kartini Kartono. Jakarta: PT. Raja Grafindo Persada.

Herwanto, J. (2004). Hubungan Antara Kecerdasan Emosi dan Efikasi Diri dengan Stres Kerja. Tesis, tidak diterbitkan: Yogyakarta, Universitas Gadjah Mada.

Hidayat, F. \& Prakosa, H. (1997). Motivasi Berprestasi dan Stres Kerja Wartawan Republika. Anima, 8 (3), 50-61. Online. Diakses dari http://www.anima.ubaya.ac.id. Pada 16 Mei 2014. 
Indonesia. (2003). Undang-undang Nomor 20 tahun 2003 Tentang Sistem Pendidikan Nasional. Jakarta: Kementerian Negara. Online. http://kemenag.go.id. Diakses 30 Maret 2014.

Ingarianti, T. M. (2009). Pelatihan Manjemen Stres Pada Guru Playgroup dan Taman KanakKanak. Jurnal Dedikasi, 6 (7), $107-$ 116. Online. Diakses dari http://ejournal.umm.ac.id. Pada 27 April 2014.

Istijanto. (2008). Riset Sumber Daya Manusia. (Edisi Ketiga). Jakarta : PT. Gramedia Pustaka.

Lilik, S. (2007). Stres Kerja pada Guru Ditinjau dari Dukungan Sosial dan Masa Kerja. Skripsi. Online. Diakses dari http://eprints.unika.ac.id. Diakses 20 Mei 2014.

Mangkunegara, A. A. A. P. (2010). Evaluasi Kinerja SDM. Bandung: Refika Aditama.

Munandar, A. S. (2011). Psikologi Industri dan Organisasi. Jakarta: UI Press.

Rivai, V. \& Mulyadi, D. (2009). Kepemimpinan dan Perilaku Organisasi. Jakarta: Rajawali Press.

Robbins, S. P. \& Judge, T. A. (2008). Perilaku Organisasi. Terjemahan oleh Diana Angelica. Jakarta: Salemba Empat.

Siagian, S. P. (2007). Manajemen Sumber Daya Manusia. Bandung: Alfabeta.

Snead, K \& Harrel, A. (1991). The Impact of Psychological Factors on the Job Satisfaction of Senior Auditor. Behavioral Research in Accounting. 3 (4), 85-96. Diakses dari http://www2.aaahq.org. Pada 2 Mei 2015.

Sugiyono. (2013). Metode Penelitian Kuantitatif dan Kualitatif dan $R$ \& $D$. Bandung: Alfabeta.

Wardana, D. S. (2013). Motivasi Berprestasi dengan Kinerja Guru yang Sudah Disertivikasi. Jurnal Ilmiah Psikologi Terapan. 1 (9) 97107. Online. Diakses dari http://erjournal.umm.ac.id. Pada 25 Maret 2015.

Yulianti. (2008). Pengaruh Motivasi terhadap Stres Kerja dan Kinerja Karyawan Koperasi Nusantara Daerah KORWIL V Jawa Barat. Tesis. Bandung: Universitas Widyatama.

Yuwono, I., Suhariadi, F., Handoyo, S., Fajrianthi, Muhamad, B. S., \& Septiarini, B. G. (2005). Psikologi Industrial \& Organisasi. Surabaya: Fakultas Psikologi Universitas Airlangga. 